NBER WORKING PAPER SERIES

\title{
DO TRUSTEES AND ADMINISTRATORS MATTER? DIVERSIFYING THE FACULTY ACROSS GENDER LINES
}

\author{
Ronald G. Ehrenberg \\ George H. Jakubson \\ Mirinda L. Martin \\ Joyce B. Main \\ Thomas Eisenberg \\ Working Paper 15606 \\ http://www.nber.org/papers/w15606
}

\author{
NATIONAL BUREAU OF ECONOMIC RESEARCH \\ 1050 Massachusetts Avenue \\ Cambridge, MA 02138 \\ December 2009
}

We are grateful to Dr. Merrill P. Schwartz, Director of Research for the Association of Governing Boards of Universities and Colleges (AGB) for aiding us to collect the information on the gender composition of boards of trustees that we use in the paper and to the Andrew W. Mellon Foundation for their financial support of the Cornell Higher Education Research Institute. However, the views expressed here are solely our own and not necessarily those of the acknowledged institutions nor of the National Bureau of Economic Research.

NBER working papers are circulated for discussion and comment purposes. They have not been peerreviewed or been subject to the review by the NBER Board of Directors that accompanies official NBER publications.

(C) 2009 by Ronald G. Ehrenberg, George H. Jakubson, Mirinda L. Martin, Joyce B. Main, and Thomas Eisenberg. All rights reserved. Short sections of text, not to exceed two paragraphs, may be quoted without explicit permission provided that full credit, including () notice, is given to the source. 
Do Trustees and Administrators Matter? Diversifying the Faculty Across Gender Lines Ronald G. Ehrenberg, George H. Jakubson, Mirinda L. Martin, Joyce B. Main, and Thomas Eisenberg NBER Working Paper No. 15606

December 2009

JEL No. I2,I21,J16

\begin{abstract}
$\underline{\text { ABSTRACT }}$
Our paper focuses on the role that the gender composition of the leaders of American colleges and universities -trustees, presidents/chancellors, and provosts/academic vice presidents - plays in influencing the rate at which academic institutions diversify their faculty across gender lines. Our analyses make use of institutional level panel data that we have collected on for a large sample of American academic institutions.
\end{abstract}

We find that, other factors held constant including our estimate of the "expected" share of new hires at an institution that should be female, that institutions with female presidents/chancellors and female provosts/academic vice presidents, and those with a greater share of female trustees, increase their shares of female faculty at a more rapid rate. The magnitudes of the effects of these leaders are larger at smaller institutions, where central administrators may play a larger role in faculty hiring decisions. A critical share of female trustees must be reached before the gender composition of the board matters.

\author{
Ronald G. Ehrenberg \\ Cornell Higher Education Research Institute \\ 271 Ives Hall East \\ Ithaca, NY 14853-3901 \\ and NBER \\ rge2@cornell.edu \\ George H. Jakubson \\ Cornell Higher Education Research Institute \\ 257 Ives Hall \\ Ithaca, NY 14853-3901 \\ George.Jakubson@cornell.edu \\ Mirinda L. Martin \\ Cornell Higher Education Research Institute \\ 273 Ives Hall \\ Ithaca, NY 14853-3901 \\ mlm299@cornell.edu
}

\author{
Joyce B. Main \\ Cornell Higher Education Research Institute \\ 273 Ives Hall \\ Ithaca, NY 14853-3901 \\ jbm245@cornell.edu \\ Thomas Eisenberg \\ Cornell Higher Education Research Institute \\ 273 Ives Hall \\ Ithaca, NY 14853-3901 \\ teisenb1@swarthmore.edu
}




\section{Introduction}

Between 1977 and 2007 the percentage of new of doctoral recipients from American universities that is female increased from 24.8 to 45.4 percent; the percentages in science and engineering fields increased at even more rapid rates. ${ }^{1}$ While the percentage of faculty that is female has increased at American 4-year colleges and universities during the same period, the rate of increase has varied across institutions and females remain under represented relative to their shares of new doctoral recipients at our nation's research universities, especially in science and engineering fields. Several recent National Research Council (NRC) reports have called attention to this discrepancy and some researchers have found evidence that females are more likely to major in science and engineering fields if the faculty in their introductory level classes are also female. ${ }^{2}$

Our paper focuses on the role that the gender composition of the leaders of American colleges and universities - trustees, presidents/chancellors, and provosts/academic vice presidents - plays in influencing the rate at which academic institutions diversify their faculty across gender lines. While there has been previous research that addresses the role that the gender composition of corporate leaders and corporate boards plays in influencing outcomes at corporations, including the gender mix of management, there has been no previous research that addresses whether the gender mix of academic leaders similarly matters. ${ }^{3}$ Our analyses make use of institutional level panel data that we have

\footnotetext{
${ }^{1}$ The comparable percentage increases in the physical sciences, engineering and the life sciences were 9.8 to $28.1 \%$, 2.8 to $20.7 \%$, and 20.8 to $51.4 \%$ respectively (Doctorate Recipients from United States Universities: Summary Report 2007 (2009), table 3)

${ }^{2}$ The NRC reports are Beyond Barriers (2007) and Gender Differences (2009). The studies include Kevin Rask and Elizabeth Bailey (2002) and Scott Carrell, Marianne Page and James West (2009). Eric Bettinger and Bridget Long (2005) do not find evidence supporting the importance of having a female faculty member on female students' choices of majors.

${ }^{3}$ See, for example, Lois Joy and Sarah Lang (2007), Alison Konrad, Vicki Kramer and Sumru Erkut (2008) (2007), Firdan Ana Kurtuslu and Donald Toaskovic-Devey (2008), Diana Bilimoria (2006), Francine Blau
} 
collected on the gender composition of trustees, presidents/chancellors, and provosts/ academic vice presidents at a large sample of American colleges and universities, as well as data on the gender mix of faculty and other variables that is collected annually as part of the IPEDS system.

The next section describes the data that we use in our analyses and provides some descriptive statistics. Section III provides our analytic framework and econometric results follow in the next two sections. A concluding section provides a summary of our key findings.

\section{Data}

Table 1 presents data from IPEDs on the shares of full-time professorial level faculty that were female at 1398 4-year colleges and universities in the United States. The sample is all 4-year institutions classified as bachelors, masters or doctoral institutions for which data were available in both 1984 and 2007.The mean share of female faculty increased from .220 to .405 during the 23 year period. In each year the share varied across types of institutions, being highest at the masters and lowest at the doctoral institutions and, within each institutional category, varied widely across institutions.

The last panel of the table reports the mean changes in the share of female faculty in each institutional category over the 23 year period. While for the entire sample and each of the institutional categories, the mean change in the female faculty share during the period was about .18 to .19 , for the sample as a whole and within each category, there was considerable variation in the change in the female faculty shares. The focus in our paper will be in testing whether, other factors held constant, the gender of an institution's

and Jed Devaro (2007), William Carrington and Kenneth Troske (1998), and Lisa Cohen, Joseph Broschak and Heather Haverman (1998). Laura Giuliano, David Levine and Jonathan Leonard similarly investigate the influence of managers' race on the race of new hires using personnel data from a large U.S retail firm. 
trustees and academic leaders influences the speed with which the institution diversified its faculty across gender lines.

Information on the gender composition of voting members of boards of trustees and the gender of board chairs comes from a survey that the Cornell Survey Research Institute conducted for the Cornell Higher Education Research Institute (CHERI), under the auspices of the Association of Governing Boards of Universities and Colleges (AGB). ${ }^{4}$ Under conditions of strict confidentiality, the AGB provided CHERI with contact information for a sample of 745 4-year colleges and universities (a subset of the institutions whose data underlie table 1). Survey questionnaires, along with a cover letter, were mailed to institutions in March 2008, with follow up letters and phone calls taking place in April of 2008 and the second half of July 2008. When data collection was completed at the end of August 2008, 509 completed responses had been received, 221 institutions refused to participate or did not respond to the survey and 15 institutions proved to be duplicates (more than one address was given to us for the same institution) or branch campuses of an institution whose board was the same as the main campus. Hence the response rate to the survey was 69.7\% (509/730). These 509 responses actually represent 593 campuses because a number of the responses were from public university systems whose boards were responsible for multiple campuses.

To say that the response rate was $69.7 \%$ is not to say that each responding institution reported data for all years between 1981 and 2007. As one might expect, institutions were more likely to report data for more recent years. For example, while 502 respondents reported data on the gender composition of their boards for 2007, the number of

\footnotetext{
${ }^{4}$ More details about the survey and the survey results are found in Ronald Ehrenberg and Joyce Main (2009) and on the CHERI web page (www.ilr.cornell.edu/cheri )
} 
respondents declined to 376 by 1981. Similarly, the number reporting the gender of the board chair declined from 503 in 2007 to 341 in 1981.

The decline in the response to the survey as one goes further back in time may lead to concerns that changes over time in the share of board with female chairs and in the average shares of board members that are female may be distorted by the changing composition of the institutions in the sample that are reporting data in each year. However, this proves not to be the case; the trends we found using data for all of the institutions that reported data in a given year are very similar to the trends that we found when we restricted the analyses to the subsample of institutions that reported data in every year. ${ }^{5}$ The average share of board members that is female rose steadily from about 0.20 in 1981 to about 0.31 in 2007. Similarly the share of board chairs that are female rose from slightly under 0.10 in 1981 to about 0.18 in $2007 .{ }^{6}$

Research on corporate boards has found that while having one or two females on a board can make a difference in board operations, it usually takes three or more women on board to achieve the "critical mass" needed to cause fundamental change on the board and to enhance the contributions that female board members make. ${ }^{7}$ The shares of board in our sample with at least three female members rose from about 0.6 in 1981 to about 0.9 in 2007; the comparable increase for the share of boards with at least five female members was from about 0.4 to 0.6 . Our econometric analyses will test if the gender of the board chair and either the share of female trustees, or a "critical mass" of female trustees, influence the rate at which institutions diversity their faculty along gender lines.

\footnotetext{
${ }^{5}$ Ehrenberg and Main (2009)

${ }^{6}$ The share of board chairs that is female and the share of board members that is female are also lowest each year at the doctoral institutions than at the masters and baccalaureate institutions.

${ }^{7}$ Konrad, Kramer and Ekrut (2008)
} 
Annual data on the gender of the president/chancellor and the provost/academic vice president at each of the 593 campuses for which we have information on the gender composition of trustees was obtained from the annual publication Higher Education Directory. In cases where the gender of an individual could not be ascertained with certainty from the name, we searched the web to confirm the individual's gender. During the 1983 to 2007 period, the share of presidents/chancellors in the sample that was female rose from 0.098 to 0.233 , while the share of provosts/academic vice presidents that was female rose from 0.140 to 0.342 . Public institutions were less likely than private institutions to have female senior academic administrators. The proportion of presidents/chancellors that was female was highest each year at baccalaureate institutions and lowest at the doctoral institutions, while the proportion of provosts/academic vice presidents that was female was lowest at the doctoral institutions in each year.

\section{Analytic Framework}

Given the share of faculty that is female at an institution in one year, the share that is female in the next year depends upon the turnover rates of female and male faculty and the share of new hires that is female. Estimates of faculty turnover rates, by institution and year, can be computed from the annual American Association of University Professor salary survey making use of the survey information on the number of continuing faculty reported by an institution in a year and then comparing this to the number of faculty reported by the institution in the previous year. ${ }^{8}$ However, sadly one cannot compute faculty turnover rates by gender from these data. So in what follows we are unable to control for differences in faculty turnover rates by gender.

\footnotetext{
${ }^{8}$ See Ronald Ehrenberg, Hirshel Kasper and Daniel Rees (1991)
} 
Our basic analytical approach is to use institutional level panel data to estimate equations of the form

(1) $\mathrm{F}_{\mathrm{it}}=\mathrm{a}_{0}+\mathrm{a}_{1} \mathrm{~F}_{\mathrm{it}-1}+\mathrm{a}_{2} \mathrm{EXP}_{\mathrm{it}-1}+\mathrm{a}_{3} \mathrm{FS}_{\mathrm{it}-1}+\mathrm{a}_{4} \mathrm{CTit}_{-1}+\mathrm{a}_{5} \mathrm{ST}_{\mathrm{it}-1}+\mathrm{a}_{6} \mathrm{PRES}_{\mathrm{it}-1}+\mathrm{a}_{7} \mathrm{PROV}_{\mathrm{it}-1}+$ $\mathrm{e}_{\mathrm{it}}$

Equation (1) specifies that the share of faculty that is female at an institution in a period (F) depends upon the share of faculty that was female in the previous period, the “expected share” of new faculty hires that was female in the previous period (EXP), the share of female students at the institution in the previous period (FS), the gender of the chair of the board of trustees, president/chancellor and provost/academic vice president (CT, PRES, PROV) in the previous period, the share of trustees that were female in the previous period (ST) and an error term (e), whose properties we will discuss later.

The lagged female faculty share variable is important because of the inertia in the process (low levels of faculty turnover) and because prior research suggests that female faculty turnover depends upon the share of female colleagues in a department, that females are more likely to be hired in science and engineering fields at research universities when there are females on the search committee, and that the proportion of tenured law school faculty members that is female influences the probability that new female candidates for tenure are awarded tenure. ${ }^{9}$

The share of new doctoral recipients granted by American universities that are women varies widely across fields in any year. For example, in 2007, the female share of new doctorates was 0.51 in the life sciences, 0.28 in the physical sciences, 0.59 in the social sciences, 0.21 in engineering, 0.67 in education, and 0.49 in the humanities. ${ }^{10}$

\footnotetext{
${ }^{9}$ Pamela S. Tolbert, Tal Simons, Alice Andrews, and Jaehoon Rhee (1995), Gender Differences (2009)

${ }^{10}$ Doctorate Recipients from United States Universities (2009), table 3, and Richard Chused (1988)
} 
Because of this, the "expected share" of new faculty hires that is female will vary across universities with the share of faculty at an institution that are employed in different fields and with the probabilities that faculty vacancies occur in each field. While data on faculty employment by field is not available for all the institutions in our sample, IPEDs does collect data on the number of degrees granted in each field. If one is willing to assume that the shares of faculty employed at an institution in each field are roughly proportional to the shares of degrees granted at the institution in each field and that faculty hiring at an institution in a year in each field is roughly proportional to the existing number of faculty in the field at the institution, then we can construct the expected share of new faculty hires that will be female in a year as the sum over all the fields in which degrees are granted at the university of the product of the share of degrees granted in each field times the share of new PhDs produced nationwide in the field that are female. Our expectation is that holding lagged female faculty share constant, an increase in the expected share variable will be associated with an increase in the female faculty share in the current period. We use 2-digit Classification of Instruction (CIP) codes to develop our expected supply variable. There are approximately 50 of these subject matter codes, but the number of PhDs produced in several of these fields is zero in many years. For later reference, we note that the mean value of our expected share variable in our sample was 0.40 and the $25^{\text {th }}$ to $75^{\text {th }}$ percentile range was about 0.36 to 0.47 .

The lagged share of female students (FS) is included as an explanatory variable to see if institutions with higher shares of female students, other factors held constant, are likely to hire more female faculty. Finally, the other variables included in the analysis are the ones that are of primary concern to us: the gender composition of the trustees and the 
genders of the board chair, the president/chancellor and the provost/academic vice president.

\section{Econometric Results}

Table 2 presents estimates of equation (1) using institutional level panel data for 583 institutions during the 1984-2007 period. ${ }^{11}$ The estimates in column (1) are GLS estimates that assume institutional level random effects, those in column (2) are from an institutional level fixed effects model, while those in columns (3) and (4) are from weighted random and fixed effects models, where the weights are the square root of the number of faculty at an institution.

As expected the lagged female faculty share variable is a strong predictor of the female faculty share variable in a year. Holding constant the lagged female faculty supply, the expected share of new faculty hires that is female also matters. An increase in the expected share of 0.10 , (slightly less than the difference between the $25^{\text {th }}$ percentile and $75^{\text {th }}$ percentile value of the variable in the sample) is associated with a roughly 0.011 to 0.018 increase in the female faculty share in the year. This contrasts to the mean annual increase of 0.0064 during the sample period. The share of female students also matters. Other factors held constant, an increase in the share of female students of 0.1 is associated with an increase in the female faculty share of roughly 0.002 to 0.007 in a year.

Turning to the variables of primary interest to us, the genders of the chair of the board, the president/chancellor and the provost/academic vice president, as well as the share of the board of trustees that is female, all are associated with a more rapid increase in the

\footnotetext{
${ }^{11}$ Ten of the institutions for which we had trustee data were eliminated from the econometric analyses because they are specialized institutions, such as religious seminaries and art institutes. Dichotomous variables were also included in the estimation to control for non reporting of the gender of the chair of the board and the gender composition of the board for an institution in a year.
} 
share of faculty that are female. The gender of the board chair, however, is not significantly related to this outcome. The marginal impacts of having a female president or a greater share of trustees that is female are both smaller in the weighted random and fixed effects models than they are in the unweighted random and fixed effects models; this suggests that the effects are smaller at the larger institutions in which hiring decisions are much more decentralized. Put another way, the gender of the leaders appears to influence the speed with which institutions diversify their faculty along gender lines more at smaller institutions than it does at larger ones.

The magnitudes of these trustee and senior administrator effects are quite large. Focusing on the weighted estimates, which are the smallest of the four models, having a female president/chancellor is associated, with an increase in the share of female faculty in a year of 0.002, holding other factors, including the lagged female faculty share and our expected supply variable constant. Having a female provost is associated with a slightly smaller effect. Each of these effects is about one-third the size of the mean yearto-year increase in the female faculty share in the sample. Similarly, other factors held constant, an increase in the share of female trustees of .10 (say an increase from .20 to .30 is associated with an increase in the female faculty share of about 0.0005 ; this is about one quarter of the magnitude of the effect of having either a female president/chancellor or provost/academic vice president.

One might reasonably be concerned about whether having a female board chair or a higher share of female trustees increases the probability of observing a female president/chancellor or a female provost/academic vice president and visa versa. That is, is it meaningful to talk about varying the gender of administrators, holding constant the 
gender of board members, and visa versa? Fortunately, the magnitudes of the president and provost coefficients that we obtain are about the same as those found in table 2 when we omit the trustee variables from equation (1) and the magnitudes of the trustee coefficients that we obtain when we omit the president and provost variables from equation (1) are about the same as those found in table 2 when we omit the president and provost variables from the equation.

The coefficient estimates we obtain from the random effects models (columns 1 and 3 ) are very similar to the coefficients that we obtain from the comparable fixed effects models (column 2 and 4). Any unobserved institution effect that leads some institutions to diversify their faculty more rapidly along gender lines than other institutions would also cause the former institutions lagged share of female faculty to be larger than the latter's lagged share. The similarity between our random effects and fixed effects model coefficients suggests that our controlling for the lagged female share on the right hand side of our model also has controlled for these unobserved institutional effects. Consequently, the discussion that follows will focus on the random effects model. ${ }^{12}$

Does the impact of the share of trustees that is female depend upon some "critical mass” of the female trustee share being achieved, or some critical number of female trustees? The estimates presented in tables 3 and 4 provide answers to these questions.

The estimated in table 3 are based on a variant of equation (1) in which the continuous share of female trustee variables is replaced by a set of dichotomous variables representing that indicate whether the share of trustees is between .050 and .099

\footnotetext{
${ }^{12}$ Consider the general panel data model $Y_{i t}=B X_{i t}+\left(c_{i}+e_{i t}\right)$ where the $c_{i}$ are fixed effects and $e_{i t}$ is a random error term. If the $\mathrm{C}_{\mathrm{i}}$ are uncorrelated with the $\mathrm{X}_{\mathrm{it}}$ then both the fixed and random effects estimators are consistent estimators for $\mathrm{B}$. If $\mathrm{c}_{\mathrm{i}}$ is correlated with the $\mathrm{X}_{\mathrm{it}}$ then the random effects estimator is biased. The similarity of our results when we use the fixed and random effects methods suggests that once for control for the lagged female share, any remaining bias is negligible.
} 
(prop5), .100 and .149 (prop10), .150 to .199 (prop15), .200 to .249 (prop20), .250

to .299 (prop25), .300 to .349 (prop30), .350 to .399 (prop35) or .400 or greater (prop40). The omitted category is a share of female trustees of less than .050, so the coefficients of each of these variables represents the "effect" of having a female trustee share in the interval relative to having a female trustee share of less than .05 .

Quite strikingly, the coefficients of prop5, prop10, prop15, and prop20 are all roughly equal in magnitude and statistically insignificantly different from zero. However, the coefficient of prop25 is roughly double in magnitude and is statistically significant from zero. This suggests that a female share of trustees of at least .25 is required for these trustees to have a significant impact on the speed with which academic institutions diversify their faculty across gender lines. While the coefficient of prop30 is of the same order of magnitude as that of prop25, the coefficient of prop35 is about one and half times as large and that of prop40 more than twice as large, suggesting that the marginal impact of the female trustee share on the share of female faculty does increase once the female board share is more than a third.

Table 4 presents estimates of variant of equation (1) in which the share of female trustees is replaced by dichotomous variables for one female trustee (board1), two female trustees (board2), three female trustees (board3), four female trustees (board 4) or five or more female trustees (board5). These estimates suggest that the number of female trustees on the board must be at least 5 for them to have a statistically significant effect on the share of faculty that is female. Other variables held constant (including the lagged female faculty share), having at least five female trustees is associated with a female faculty share that is .008 higher. Moreover, in this specification, the gender of the board 
chair also proves important; holding other variables constant, having a female board chair in the previous period is associated with a .0034 higher share of faculty that is female. ${ }^{13}$

\section{Extensions and Specification Tests}

Table 5 presents random effects estimates of equation (1) done separately for public institutions, private institutions, baccalaureate colleges, masters' institutions and doctoral institutions. Because in each case the sample size used in the estimation is considerably smaller than the overall sample, the probability of our observing statistically significant coefficients is substantially smaller than in table 2 . Hence we "liberally" interpret significance in this table to include significance at the 0.10 level.

The lagged "expected supply” variable is statistically significantly positively associated with the share of female faculty for each group of institutions. The presence of a female president or a female provost in the previous year, is positively associated with the share of female faculty for each group (and significantly so for 8 of the 10 coefficients) and, the magnitude of the effects for both is largest for the baccalaureate institutions, where central administrators are likely to play larger roles in the faculty hiring process as we conjectured above. While the share of trustees that is female in the previous year is significantly positively associated with the share of female faculty for four of the five specifications, the relationship for doctoral institutions is negative (but significant only at the 0.10 level).

\footnotetext{
${ }^{13}$ This is above and beyond the impact of having one female trustee, which is a statistically insignificant .001. We also attempted to include the dichotomous variables for both the female trustee shares and the numbers of females in the same model, but colinearity prevented us from getting any statistically significant affects in this model.
} 
The number of new faculty hired at an institution in a year, by gender, is available from IPEDs for 9 of the years in our sample period (1993, 1995, and 2001-2007). Not all institutions hire any faculty members in each year, but for the subsample that do each year, these data permit us to estimate a variant of equation (1) in which the dependent variable is the share of newly hired faculty members in the year that are female. Random effects estimates of this equation appear in table 6.

The coefficients of the "expected supply" variable, the gender of the president and the provost, the share of trustees that are female and the gender of the chair of the board of trustees are all female in this model, but none of them are statistically significantly different from zero. However, because the sample size used in the estimation in table 4 is about one third that used in table 2, the "t" statistics for the coefficients found in this table would be roughly 1.7 times larger if the sample size was the same as in table 2. A perusal of the standard errors of these coefficient estimates suggests that all of these coefficients, save for the gender of the board chair, would have been statistically significantly different from zero with the larger sample size. Perhaps more important the magnitudes of these coefficients are all larger (in absolute value) than the comparable coefficients found in the first column of table 2 .

Finally, we are very sensitive to the fact that we have include a lagged dependent variable among our explanatory variables in our models and that this may lead to biased estimates of all of the coefficients in the models. In an attempt to control for this problem, we used an instrumental variable method similar to that used by Kurtulus and Tomaskovic-Devey (2008) in their study of the effect of female managers on the subsequent representation of females in management in U.S. firms. Basically, we 
obtained an instrument for the lagged female faculty share by regressing the lagged female share on the lagged and lagged two period values of the expected female faculty supply variable, the share of female students, the genders of the board chair, president and provost, and the share of trustees that is female, as well as the lagged two period value of the female faculty share. ${ }^{14}$

Estimates of equation (1) that we obtained using this method are found in table 7 and they are qualitatively very similar to the random effects model results found in column 1 of table 2. The expected female share of new hires and the gender of the board chair, the president/chancellor and provost/academic vice president in the previous period are all statistically significantly positively related to the current female faculty share, other variables, including our instrument for the lagged female faculty share held constant. The magnitude of each of these effects is somewhat smaller than the comparable effect found in table 2, but qualitatively each remains important. ${ }^{15}$

\section{Concluding Remarks}

Our paper has shown that the genders of leaders of America's 4-year colleges and universities - trustees, presidents/chancellors, and provosts/academic vice presidents - are associated with the rate at which these institutions have diversified their faculty across gender lines during the 1984-2007 period. Other factors held constant, including our estimate of the "expected" share of new hires at an institution that should be female in a year, we find that institutions with female presidents/chancellors and female

\footnotetext{
${ }^{14}$ This procedure produces a valid instrument if the disturbance term is autocorrelated at no more than one lag. Given that we already have included a lagged dependent variable in our model, this specification allows for a great deal of dependence over time.

${ }^{15}$ When we reestimated this instrumental variable model clustering the standard errors by institution, the estimated coefficients remained the same but the statistical significance of the estimates declined
} 
provosts/academic vice presidents, and with a greater share of female trustees, increase their share of faculty that are female at more rapid rates, Moreover, the magnitudes of the effects of these leaders appears to be largest at smaller institutions, where central administrators may play a greater role in faculty hiring decisions. We also found that there appears to be a critical share of female trustees (25\%) or a critical number of female trustees (5) that must be reached before the gender composition of the board of trustees influences the rate of diversification of the faculty across gender lines.

Our study is only a first look at how the gender mix of leaders influences outcomes at academic institutions. It would be fruitful to extend our analyses to study how the gender of administrators "on the ground" who are more directly involved with hiring and retention efforts - deans and department chairs - influences the rate at which the faculty is diversified across gender lines. And we need to understand better why the gender of leaders matters. For example, the report of a recent National Research Council Committee, upon which one of us served, found evidence that the gender of the chair of a faculty search committee in science and engineering fields at major research universities influences the likelihood that female PhDs will apply for the position; apparently knowledge of the gender of the chair of the search committee signals something to potential female applicants about the seriousness of the department in wanting to expand female faculty employment and in providing leadership opportunities for female colleagues. ${ }^{16}$

${ }^{16}$ Gender Differences (2009) 


\section{References}

Eric Bettinger and Bridget Terry Long, “”Do Faculty Serve as Role Models? The Impact of Instructor Gender on Female Students”, American Economic Association Papers and Proceedings 95 (May 2005): 152-157

Beyond Bias and Barriers: Fulfilling the Potential of Women in Academic Science and Engineering (Washington DC: National Academy Press, 2007)

Diana Bilimoria, “The Relationship Between Women Corporate Directors and Women Corporate Officers”, Journal of Managerial Issues 18 (Spring 2006): 47-61

Francine D. Blau and Jed L. DeVaro, "New Evidence on Gender Differences in Promotion Rates: An Empirical Analysis of a Sample of New Hires”, Industrial and Relations 46 (April 2007): 511-550

Scott Carrell, Marianne Page, and James West, “Sex and Science: How Professor Gender Perpetuates the Gender Gap”, National Bureau of Economic Research Working Paper No. 14959 (Cambridge MA: National Bureau of Economic Research, May 2009)

William J. Carrington and Kenneth R, Troske, “Sex Segregation in U.S. Manufacturing”, Industrial and Labor Relations Review 51 (April 1998): 445-464

Richard H. Chused, “The Hiring and Retention of Minorities and Women on American Law School Faculties”, University of Pennsylvania Law Review 137 (December 1988): 537-569

Lisa E. Cohen, Joseph P Broschak and Heather Haverman, “And Then There Were More? The Effect of Organizational Sex Composition on the Hiring and Promotion of Managers”, American Sociological Review 63 (October 1998): 711-727 
Doctoral Recipients from United States Universities: Summary Report 2007

(Chicago IL: NORC at the University of Chicago, 2009)

Ronald G. Ehrenberg, Hirschel Kasper and Daniel Rees, "Faculty Turnover at American Colleges and Universities: Analyses of AAUP Data”, Economics of Education Review 10 (April 1991): 99-110

Ronald G. Ehrenberg and Joyce B. Main, "Females on Academic Boards of Trustees: Slow But Steady Progress”, Trusteeship 17 (March/April 2009): xx-yy

Gender Differences at Critical Transitions in the Careers of Science, Engineering and Mathematics Faculty ((Washington DC: National Academy Press, 2009)

Laura Giuliano, David I. Levine, and Jonathan Leonard, "Manager Race and the Race of New Hires”, Journal of Labor Economics 27 (October 2009): 589-632

Higher Education Directory (Falls Creed VA: Higher Education Publications Inc., year)

Lois Joy and Sarah Lang., "Do Women in Top Corporate Management and Governance Help Women to Advance?” (Paper presented at the May 2007 Society of Labor Economists meeting, Chicago IL.)

Alison Konrad, Vicki Kramer and Sumru Erkut, "Critical Mass: The Impact of Three or More Women on Corporate Boards”, Organizational Dynamics 37 (April-June 2008): $145-164$

Fidan Ana Kurtulus and Donald Tomaskovic - Devey, "Do Women Managers Help Women Advance? A Panel Study Using EEO-1 Records” (Working Paper, Department of Economics, University of Massachusetts Amherst, January 2008) 
Kevin Rask and Elizabeth Bailey, “Are Faculty Role Models? Evidence from Major Choice in an Undergraduate Institution”, Journal of Economic Education 33 (Spring 2002): 99-124

Pamela S. Tolbert, Tal Simons, Alice Andrews, and Jaehoon Rhee, "The Effect of Gender Composition in Academic Departments on Faculty Turnover”, Industrial and Labor Relations Review 48 (April 1995): 562-579 
Table 1

Female Faculty Shares at 4-Year Institutions: 1984 - 2007

\begin{tabular}{|l|l|l|l|l|l|l|l|l|l|l|}
\hline & & \multicolumn{3}{|c|}{1984 Female Share } & \multicolumn{3}{c|}{ 2007 Female Share } & \multicolumn{3}{c|}{ Change in Share 1984 to } \\
\hline & Obs & 25th \%ile & Mean & 75th \%ile & 25th \%ile & Mean & 75th \%ile & 25th \%ile & Mean & 75th \%ile \\
\hline $\begin{array}{l}\text { Entire } \\
\text { Sample }\end{array}$ & 1398 & 0.118 & 0.220 & 0.283 & 0.341 & 0.405 & 0.461 & 0.128 & 0.185 & 0.253 \\
\hline Bachelors & 478 & 0.116 & 0.226 & 0.309 & 0.349 & 0.413 & 0.466 & 0.112 & 0.187 & 0.278 \\
\hline Masters & 521 & 0.157 & 0.259 & 0.324 & 0.378 & 0.436 & 0.476 & 0.124 & 0.178 & 0.247 \\
\hline Doctoral & 250 & 0.101 & 0.157 & 0.192 & 0.299 & 0.342 & 0.380 & 0.157 & 0.186 & 0.219 \\
\hline Public & 584 & 0.136 & 0.209 & 0.262 & 0.343 & 0.392 & 0.441 & 0.146 & 0.183 & 0.232 \\
\hline Private & 814 & 0.102 & 0.228 & 0.305 & 0.341 & 0.414 & 0.474 & 0.111 & 0.186 & 0.276 \\
\hline
\end{tabular}

*Note: 149 specialized institutions (e.g. seminaries, art institutes, and health related colleges) included in the entire sample are not included in the bachelors, masters, or doctoral institution categories 
Table 2

Random Effects, Fixed Effects, and Weighted Fixed Effects Estimates of the Determinants of the Share of Female Faculty

\begin{tabular}{|l|l|l|l|l|}
\hline & Random Effects & Fixed Effects & $\begin{array}{l}\text { Weighted } \\
\text { Random Effects }\end{array}$ & $\begin{array}{l}\text { Weighted Fixed } \\
\text { Effects }\end{array}$ \\
\hline F & & & & \\
\hline & $0.788^{* * *}$ & $0.683^{* * *}$ & $0.814^{* * *}$ & $0.809^{* * *}$ \\
\hline EXP & $(0.00516)$ & $(0.00621)$ & $(0.00515)$ & $(0.00528)$ \\
\hline & $0.111^{* * *}$ & $0.183^{* * *}$ & $0.131^{* * *}$ & $0.135^{* * *}$ \\
\hline FS & $(0.00687)$ & $(0.00783)$ & $(0.00550)$ & $(0.00564)$ \\
\hline & $0.0650^{* * *}$ & $0.0156^{* *}$ & $0.0210^{* * *}$ & $0.0180^{* * *}$ \\
\hline PRES & $(0.00491)$ & $(0.00697)$ & $(0.00484)$ & $(0.00498)$ \\
\hline & $0.00722^{* * *}$ & $0.00544^{* * *}$ & $0.00199^{* *}$ & $0.00190^{* *}$ \\
\hline PROV & $(0.00143)$ & $(0.00159)$ & $(0.000836)$ & $(0.000845)$ \\
\hline & $0.00493^{* * *}$ & $0.00236^{* *}$ & $0.00153^{* * *}$ & $0.00151^{* *}$ \\
\hline ST & $(0.00109)$ & $(0.00114)$ & $(0.000620)$ & $(0.000626)$ \\
\hline & $0.0233^{* * *}$ & $0.0231^{* * *}$ & $0.00539^{* * *}$ & $0.00492^{* *}$ \\
\hline CT & $(0.00357)$ & $(0.00419)$ & $(0.00230)$ & $(0.00233)$ \\
\hline & 0.00198 & 0.00173 & 0.000985 & 0.000963 \\
\hline Constant & $(0.00131)$ & $(0.00135)$ & $(0.000682)$ & $(0.000690)$ \\
\hline & $-0.0140^{* * *}$ & $0.0189^{* * *}$ & 0.00170 & $-0.00578^{* *}$ \\
\hline & $(0.00316)$ & $(0.00430)$ & $(0.00393)$ & $(0.00262)$ \\
\hline Observations & 10583 & 10583 & 10583 & 10583 \\
\hline R-squared & & 0.722 & & 0.889 \\
\hline $\begin{array}{l}\text { Number of } \\
\text { institutions }\end{array}$ & 583 & 583 & 583 & 583 \\
\hline
\end{tabular}

Standard errors in parentheses

*** $\mathrm{p}<0.01,{ }^{* *} \mathrm{p}<0.05,{ }^{*} \mathrm{p}<0.1$

where

F - share of female faculty in the previous year

EXP - "expected share" of new faculty hires that is female during the previous year

FS - share of female students in the previous year

PRES - $1=$ female president/chancellor in the previous year

$0=$ otherwise

PROV - 1 = female provost/academic vice president in the previous year

$0=$ otherwise

ST - share of board of trustee members that is female in the previous year

CT $\quad-1=$ board chair is female in the previous year

$0=$ otherwise 
Table 3

Random Effects Estimates: Critical Proportions Model

\begin{tabular}{|l|l|}
\hline F & $0.787^{* * *}$ \\
\hline & $(0.00517)$ \\
\hline EXP & $0.113^{* * *}$ \\
\hline FS & $(0.00698)$ \\
\hline & $0.0652^{* * *}$ \\
\hline PRES & $(0.00498)$ \\
\hline & $0.00715^{* * *}$ \\
\hline PROV & $(0.00144)$ \\
\hline & $0.00491^{* *}$ \\
\hline CT & $(0.00109)$ \\
\hline & $0.00231^{*}$ \\
\hline Prop5 & $(0.00131)$ \\
\hline & 0.00374 \\
\hline Prop10 & $(0.00314)$ \\
\hline & 0.00280 \\
\hline Prop15 & $(0.00301)$ \\
\hline & 0.00301 \\
\hline Prop20 & $(0.00303)$ \\
\hline & 0.00252 \\
\hline Prop25 & $(0.00303)$ \\
\hline & $0.00616^{* *}$ \\
\hline Prop30 & $(0.00311)$ \\
\hline & 0.00503 \\
\hline Prop35 & $(0.00322)$ \\
\hline & $0.00926 * *$ \\
\hline Prop40 & $(0.00361)$ \\
\hline & $0.0138 * *$ \\
\hline Constant & $(0.00330)$ \\
\hline & $-0.0144^{* * *}$ \\
\hline Observations & $(0.00402)$ \\
\hline Number of & 10583 \\
\hline institutions & 583 \\
\hline & \\
\hline & \\
\hline &
\end{tabular}

Standard errors in parentheses

*** $\mathrm{p}<0.01, * * \mathrm{p}<0.05,{ }^{*} \mathrm{p}<0.1$ 
Table 4

Random Effects Estimates: Critical Number Model

\begin{tabular}{|c|c|}
\hline \multirow[t]{2}{*}{$\mathrm{F}$} & $0.788 * * *$ \\
\hline & $(0.00515)$ \\
\hline \multirow[t]{2}{*}{ EXP } & $0.111^{* * *}$ \\
\hline & $(0.00694)$ \\
\hline \multirow[t]{2}{*}{ FS } & $0.0692 * * *$ \\
\hline & $(0.00492)$ \\
\hline \multirow[t]{2}{*}{ PRES } & $0.00818 * * *$ \\
\hline & $(0.00142)$ \\
\hline \multirow[t]{2}{*}{ PROV } & $0.00488 * * *$ \\
\hline & $(0.00110)$ \\
\hline \multirow[t]{2}{*}{$\mathrm{CT}$} & $0.00341 * * *$ \\
\hline & $(0.00129)$ \\
\hline \multirow[t]{2}{*}{ Board1 } & 0.00126 \\
\hline & $(0.00377)$ \\
\hline \multirow[t]{2}{*}{ Board2 } & 0.000864 \\
\hline & $(0.00354)$ \\
\hline \multirow[t]{2}{*}{ Board3 } & 0.00413 \\
\hline & $(0.00354)$ \\
\hline \multirow[t]{2}{*}{ Board4 } & 0.00520 \\
\hline & $(0.00362)$ \\
\hline \multirow[t]{2}{*}{ Board5 } & $0.00820 * *$ \\
\hline & $(0.00352)$ \\
\hline \multirow[t]{2}{*}{ Constant } & $-0.0171 * * *$ \\
\hline & $(0.00440)$ \\
\hline Observations & 10583 \\
\hline $\begin{array}{l}\text { Number of } \\
\text { institutions }\end{array}$ & 583 \\
\hline
\end{tabular}

Standard errors in parentheses

*** $\mathrm{p}<0.01$, ** $\mathrm{p}<0.05$, * $\mathrm{p}<0.1$ 
Table 5

Random Effects Model: By Institutional Type

\begin{tabular}{|l|l|l|l|l|l|}
\hline & Private & Public & Bachelors & Masters & Doctoral \\
\hline & & & & & \\
\hline F & $0.762^{* * *}$ & $0.880^{* * *}$ & $0.765^{* * *}$ & $0.791^{* * *}$ & $0.913^{* * *}$ \\
\hline EXP & $(0.00669)$ & $(0.00713)$ & $(0.00867)$ & $(0.00792)$ & $(0.00774)$ \\
\hline & $0.112^{* * *}$ & $0.0894^{* * *}$ & $0.103^{* * *}$ & $0.114^{* * *}$ & $0.0608^{* * *}$ \\
\hline FS & $(0.00962)$ & $(0.00793)$ & $(0.0123)$ & $(0.0109)$ & $(0.00813)$ \\
\hline & $0.0666^{* * *}$ & $0.0119^{*}$ & $0.0617^{* * *}$ & $0.0724^{* * *}$ & $0.0145^{* *}$ \\
\hline PRES & $(0.00663)$ & $(0.00652)$ & $(0.00812)$ & $(0.00838)$ & $(0.00629)$ \\
\hline & $0.00865^{* * *}$ & $0.00222^{*}$ & $0.0101^{* * *}$ & $0.00480^{* *}$ & 0.00147 \\
\hline PROV & $(0.00215)$ & $(0.00130)$ & $(0.00268)$ & $(0.00214)$ & $(0.00144)$ \\
\hline & $0.00564^{* * *}$ & 0.00131 & $0.00654^{* * *}$ & $0.00370^{* *}$ & 0.000518 \\
\hline ST & $(0.00158)$ & $(0.00104)$ & $(0.00198)$ & $(0.00169)$ & $(0.00110)$ \\
\hline & $0.0373^{* * *}$ & $0.00660^{*}$ & $0.0262^{* * *}$ & $0.0301^{* * *}$ & $-0.00775^{*}$ \\
\hline CT & $(0.00659)$ & $(0.00374)$ & $(0.00833)$ & $(0.00622)$ & $(0.00406)$ \\
\hline & 0.00283 & 0.00145 & 0.000901 & 0.00219 & 0.00166 \\
\hline Constant & $(0.00224)$ & $(0.00103)$ & $(0.00250)$ & $(0.00191)$ & $(0.00142)$ \\
\hline & -0.00689 & -0.00398 & -0.000311 & $-0.0194^{* * *}$ & -0.00170 \\
\hline & $(0.00455)$ & $(0.00331)$ & $(0.00584)$ & $(0.00528)$ & $(0.00256)$ \\
\hline Observations & 6750 & 3833 & 4203 & 4249 & 2113 \\
\hline $\begin{array}{l}\text { Number of } \\
\text { institutions }\end{array}$ & 379 & 204 & 234 & 234 & 113 \\
\hline Stady & & & & & \\
\hline
\end{tabular}

Standard errors in parentheses

${ }^{* * *} \mathrm{p}<0.01,{ }^{* *} \mathrm{p}<0.05,{ }^{*} \mathrm{p}<0.1$ 
Table 6

Random Effects Model: Share of New Faculty Hires

\begin{tabular}{|l|l|}
\hline $\mathrm{F}$ & $0.200^{* * *}$ \\
\hline & $(0.0504)$ \\
\hline EXP & $0.142^{*}$ \\
\hline & $(0.0765)$ \\
\hline FS & $0.157^{* * *}$ \\
\hline PRES & $(0.0458)$ \\
\hline & 0.0124 \\
\hline PROV & $(0.0124)$ \\
\hline & 0.0157 \\
\hline ST & $(0.00978)$ \\
\hline & $0.0766^{* *}$ \\
\hline CT & $(0.0384)$ \\
\hline & 0.00562 \\
\hline Constant & $(0.0119)$ \\
\hline & $0.214^{* * *}$ \\
\hline & $(0.0295)$ \\
\hline Observations & 3690 \\
\hline $\begin{array}{l}\text { Number of } \\
\text { institutions }\end{array}$ & 562 \\
\hline Stand & \\
\hline
\end{tabular}

Standard errors in parentheses

${ }^{* * *} \mathrm{p}<0.01,{ }^{* *} \mathrm{p}<0.05,{ }^{*} \mathrm{p}<0.1$ 
Table 7

Instrumental Variables Random Effects Model

\begin{tabular}{|l|l|}
\hline F $^{\prime}$ & $0.819^{* * *}$ \\
\hline & $(0.00849)$ \\
\hline EXP & $0.0445^{* * *}$ \\
\hline & $(0.00861)$ \\
\hline FS & $0.0344^{* * *}$ \\
\hline PRES & $(0.00665)$ \\
\hline & $0.00456^{* * *}$ \\
\hline PROV & $(0.00176)$ \\
\hline & $0.00236^{*}$ \\
\hline ST & $(0.00131)$ \\
\hline & $0.0157^{* * *}$ \\
\hline CT & $(0.00544)$ \\
\hline & 0.00181 \\
\hline Constant & $(0.00154)$ \\
\hline & $0.0261^{* * *}$ \\
\hline & $(0.00429)$ \\
\hline Observations & 9472 \\
\hline $\begin{array}{l}\text { Number of } \\
\text { institutions }\end{array}$ & 582 \\
\hline
\end{tabular}

Standard errors in parentheses

$* * * \mathrm{p}<0.01, * * \mathrm{p}<0.05, * \mathrm{p}<0.1$ 